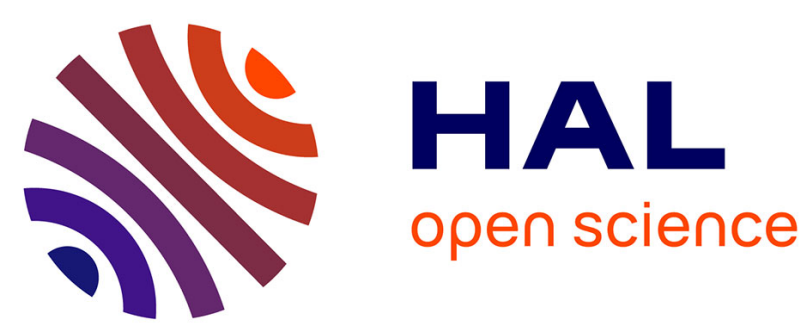

\title{
Nepal and Bhutan in 2011
}

Sara Shneiderman, Mark Turin

\section{To cite this version:}

Sara Shneiderman, Mark Turin. Nepal and Bhutan in 2011. Asian Survey, 2012, 52 (1), pp.138-146. 10.1525/as.2012.52.1.138 . halshs-03083434

\section{HAL Id: halshs-03083434 https://shs.hal.science/halshs-03083434}

Submitted on 19 Dec 2020

HAL is a multi-disciplinary open access archive for the deposit and dissemination of scientific research documents, whether they are published or not. The documents may come from teaching and research institutions in France or abroad, or from public or private research centers.
L'archive ouverte pluridisciplinaire HAL, est destinée au dépôt et à la diffusion de documents scientifiques de niveau recherche, publiés ou non, émanant des établissements d'enseignement et de recherche français ou étrangers, des laboratoires publics ou privés. 


\title{
Nepal and Bhutan in 2011
}

\author{
Cautious Optimism
}

\begin{abstract}
Nepal's political transition to a democratic federal republic remains incomplete. A November 2011 agreement on post-conflict integration and rehabilitation offers reason for hope. Continued disagreements over the structure of the federal state and its form of government have delayed the constitution-making process. Corruption, impunity, and weak infrastructure combine to erode Nepali confidence in effective governance. Bhutan's democratic exercise continues to be carefully controlled by entrenched elites, but the country held its first-ever local elections successfully and economic growth stabilized.
\end{abstract}

KEYWORDS: Nepal, Bhutan, democratic transition, constitution-making, state restructuring

\section{NEPAL}

The year 20II began with the termination of the United Nations Mission in Nepal (UNMIN). With UNMIN's departure in January, Nepal's peace process entered unmonitored territory for the first time since the mission's inception four years ago. Although controversial and ever-uncomfortable with the terms of its mandate, the U.N. intervention established the conditions for implementing the November 2006 Comprehensive Peace Agreement that ended the decade-long civil conflict between state security forces and the Maoist People's Liberation Army (PLA). With its recent focus on the most intractable aspect of the peace process - establishing a procedure for integrating eligible Maoist ex-combatants into the Nepal Army (NA) and rehabilitating the remainder-UNMIN's presence had exerted continued

Sara Shneiderman is Assistant Professor of Anthropology at Yale University. Mark Turin is Associate Research Scientist in South Asian Studies at Yale University and Research Associate at the University of Cambridge. They are grateful to Pratyoush Onta, John Whelpton, Megan Adamson Sijapati, and Hikmat Khadka for helpful input, although they take full responsibility for any errors. Emails: <sara.shneiderman@yale.edu>, <mark.turin@yale.edu>.

Asian Survey, Vol. 52, Number I, pp. I38-I46. ISSN oo04-4687, electronic ISSN I533-838X. (C) 2012 by the Regents of the University of California. All rights reserved. Please direct all requests for permission to photocopy or reproduce article content through the University of California Press's Rights and Permissions website, http://www.ucpressjournals.com/reprintInfo.asp. DOI: AS.2OI2.52.I.I38. 
pressure on political factions across the ideological spectrum to work toward lasting peace.

Years of negotiations delivered a concrete result in the form of the November I, 20II, agreement between the Unified Communist Party of Nepal-Maoist (UCPN-M), the Communist Party of Nepal-Unified Marxist Leninist (CPNUML), the Nepali Congress (NC), and the United Democratic Madhesi Front (UDMF) to integrate 6,500 Maoist combatants into the NA and rehabilitate many more. ${ }^{1}$ The seven-point agreement stipulates the creation of a Special Directorate of the NA, which would draw $65 \%$ of its personnel from the existing NA and $35 \%$ from the ranks of Maoist combatants.

UNMIN verification teams had originally identified 19,602 combatants at seven cantonment sites in 2007. But only 16,508 combatants could be located by the December I, 20II, completion of the "regrouping" process overseen by the Army Integration Special Committee (AISC), as required by the November agreement. ${ }^{2}$ The difference between these numbers has fueled longstanding speculation that PLA numbers had been intentionally inflated for political and financial gain during the UNMIN-led verification process. Such allegations-along with the fact that over $40 \%$ of the current corps opted for integration rather than retirement or rehabilitation-raised questions about the feasibility of implementing the November I agreement, which set a quota of only 6,500 combatants for integration.

Furthermore, while the agreement stipulated that the UCPN-M would disband the "paramilitary structure" of the Young Communist League and return property seized during the armed conflict by November 23, both of these processes remain unfinished and fraught with internal UCPN-M party politics. Nevertheless, the agreement still offers cause for cautious optimism. The progress on reintegration demonstrates that, despite entrenched differences, a modicum of positive political will exists and paves the way for further decisions on the structure of the federal state and its system of government.

I. Madhesi is a regional identity claimed by many residents of Nepal's southern Tarai region. Madhesi political leaders position themselves in opposition to the historically dominant elites of the hill region. The UDMF, which is also referred to in news reports as the Samyukta Loktantrik Madheshi Morcha (SLMM), is an alliance of several madhesi political parties, including the Madhesi Janadhikar Forum (Madhesi People's Rights Forum, MJF).

2. The AISC is the body charged with determining and implementing the modalities for postconflict military integration. Mandated by the 2006 Comprehensive Peace Agreement, it was only formally constituted in early 2009. Initially overseen by UNMIN, the AISC took independent control of combatant integration upon UNMIN's January $201 \mathrm{I}$ departure. 


\section{Political Maneuvering}

As UNMIN's signature jeeps disappeared from Kathmandu's streets in January 20II, the country remained without a prime minister. The political deadlock that had distracted the Constituent Assembly (CA) from its constitution-drafting responsibilities since July 20 Io continued, with a caretaker government led by Madhav Kumar Nepal of the CPN-UML unable to move forward on substantive policy issues. Sixteen rounds of CA internal voting failed to produce an acceptable prime ministerial candidate. In February 20II, a secret seven-point pact between the UCPN-M and Jhala Nath Khanal of the CPN-UML enabled him to emerge victorious in the seventeenth round of voting with the backing of Maoist lawmakers.

It was soon revealed that Khanal had not consulted his own party before signing the private agreement with UCPN-M Chairman Pushpa Kamal Dahal. Khanal was roundly condemned by factions within his own party and the NC, which remained in opposition after Khanal formed his tenuous coalition government. Particularly contentious aspects of this clandestine agreement were the proposal to create a separate armed force of Maoist ex-combatants or an alternative force that would combine the PLA with other security forces, as well as a symbiotic arrangement between the CPN-UML and UCPN-M to lead future governments "on a rotational basis."

After prolonged deadlock, there was considerable popular pressure to form a national consensus government. Khanal swore in his first cabinet members in March. The MJF joined the government thereafter, having initially remained in opposition. Khanal faced constant protest and reshuffled his cabinet five times before grudgingly resigning on August I4, even though he remained in place as caretaker prime minister until the next incumbent was confirmed. With UDMF support, Maoist Central Committee member Baburam Bhattarai defeated NC candidate Ram Chandra Poudel in a CA vote on August 28. Bhattarai was sworn in as Nepal's 35th prime minister the following day.

Bhattarai's election offered some hope that the country's extended political impasse might come to an end. Holding a Ph.D. in regional development planning from India’s premier Jawaharlal Nehru University, Bhattarai has cultivated an image as being an elusive and soft-spoken thinker, in contrast to

3. For details, refer to <http://www.southasiaanalysis.org/\%5Cnotes7\%5Cnote6I6.html>, accessed October 2I, 2OII. 
party chairman Dahal's brash populist bluster. After years of political grandstanding, many Nepalis welcomed Bhattarai's apparent ability to work toward practical solutions. With Indian power brokers claiming him as one of their own, Bhattarai has political clout in Delhi, allowing him considerable maneuverability and access to untapped resources. However, when Bhattarai's first act as prime minister was to hand over keys to containers holding PLA weapons to the AISC, he was strongly criticized by radical factions within his own party and also by international Maoist groups for betraying the revolution.

The opprobrium only increased with his signing of the Bilateral Investment Promotion and Protection Agreement (BIPPA) with India on October 2I, and the agreement on combatant integration later in November. ${ }^{4} \mathrm{~A}$ hardline faction of the UCPN-M led by Mohan Baidya and Ram Bahadur Thapa condemned these moves and threatened further unrest if Bhattarai continued to make such "mistakes." This raised the specter of a split in the party, which has actually haunted the UCPN-M since its leaders signed the Comprehensive Peace Agreement in 2006.

\section{Constitution Drafting, Identity Politics, and Citizenship}

Underlying these political machinations lies a struggle for control over Nepal's new Constitution. On May 29, the CA, whose term had already been extended for a year beyond the original May zoro deadline, reached an agreement in the eleventh hour to again extend its term by three months. Another three-month extension was passed on August 29, 20II. A Supreme Court ruling that the CA could not be extended beyond six months unless a state of emergency was declared was partially responsible for these repeated short extensions. There were continued concerns that the most substantive tasks at hand-including finding a resolution to fractious debates over federal restructuring, representative forms of government, and even systems of affirmative action - could not be accomplished within such a short time frame. Despite these reservations, reports from various subcommittees had been forwarded to the Constitutional Committee by June, and several major

4. The BIPPA provides a framework for boosting Indian investor confidence in Nepal, despite the country's weak domestic institutions. With a ten-year term, it establishes guidelines for Indian investors to claim compensation from Nepal in the event of unexpected policy changes or political disturbances. Voices from across the political spectrum accused Bhattarai of pandering to Indian political and economic interests in a manner disadvantageous to Nepal by signing the agreement. 
points of dispute had been resolved. ${ }^{5} \mathrm{~A}$ fourth and ostensibly final six-month extension was granted on November 29, affording the CA until the end of May 2012 to complete its duties. By early December 20II, the long-awaited and controversial State Restructuring Commission had been fully constituted. The Commission's terms of reference set a two-month timeframe for the nine politically appointed members to complete a report recommending a new state structure based upon the two pillars of "identity" and "capability."

In the lead-up to the May 20II CA extension, several identity-based groups launched protests demanding that the constitution-writing process be concluded swiftly and that it address all their demands. Making life difficult for citizens across the country, strikes called by the Federal Limbuwan State Council, ${ }^{6}$ the Chetri Samaj (Chetri Society), ${ }^{7}$ and the Chure Bhawar Rastriya Ekta Party (Chure Bhawar United National Party) ${ }^{8}$ were particularly wearing. The latter two groups are examples of new movements mobilized around erstwhile dominant identities - the Chetri caste and the regional identity of paharis (inhabitants of Nepal's middle hills), respectively. Both of these parties are reported to have strong local organizations in some parts of Nepal. ${ }^{9}$

Such movements can be understood as a backlash against the increasing political influence of the janajati, madhesi, and dalit movements, which have advanced proposals for ethnic federalism and various types of affirmative action policies. ${ }^{10}$ In response, ethnic activists have heightened longstanding campaigns for agra adhikar (prior rights) for indigenous peoples in specific territories. This polemical discourse is countered by donor insistence on the broader concept of samavesikaran (social inclusion) for all. The CA will need to decide on the most appropriate constitutional mechanism to both recognize differences and ensure equality before the law.

5. For details, see Martin Chautari, Policy Paper 5, "Deadlines, Democracy, and a Popular, Democratic Constitution," June 20II, at <http://www.martinchautari.org.np/>, pp. 5-6.

6. Limbuwan is the place name for the homeland claimed by Limbu ethnic activists. They demand a single federal state of Limbuwan, comprising the nine current districts of Taplejung, Panchthar, Ilam, Jhapa, Terhathum, Sankhuwasabha, Dhankuta, Sunsari, and Morang.

7. Chetri is a derivative of Kshatriya, the historical Hindu warrior and ruler caste. Chetris comprise Nepal's largest caste group, with $15.5 \%$ of the population. They speak Nepali, the national language, and are overwhelmingly Hindu.

8. Chure Bhawar is a regional term describing a low range of hills cutting across Nepal's Tarai plains region.

9. For details, see Nepal: Identity Politics and Federalism, Crisis Group Asia Report 199, January I3, 20II, pp. I9-20, at <http://www.crisisgroup.org/en/regions/asia/south-asia/nepal.aspx>.

Io. Janajati is an umbrella term for ethnic communities who refer to themselves as "indigenous nationalities." Dalit is the term of choice for "low caste" or former "Untouchables." 
New citizenship provisions proposed in $201 \mathrm{I}$ have been hotly contested. In January, Human Rights Watch criticized a draft constitutional provision that would guarantee Nepali citizenship only to children born of two Nepali parents. Such laws could lead to a "crisis of statelessness" that would impact women and children in particular. ${ }^{11}$ Cabinet Minister Lharkyal Lama was forced to resign in April when it was discovered that he held both Nepali and Indian passports, along with a Tibetan refugee card. While holding multiple documents is not uncommon in Nepal given the long open border and special relationship with India, this incident demonstrated that citizenship rights are a potentially divisive political topic.

\section{Impunity}

Impunity for perpetrators of crime, both in relation to basic law and order and also to post-conflict transitional justice, remained an issue throughout 20II. Soon after becoming prime minister, Bhattarai offered a general amnesty for "political crimes" committed during the civil conflict—a move harshly criticized by human rights organizations and his political opponents. The prime minister's controversial November pardon of Balkrishna Dhungel, a Maoist lawmaker convicted of murder, provoked a Supreme Court injunction ordering the government not to carry out the order. Security personnel similarly convicted of wartime atrocities also remain unprosecuted. On December 8, the mandate of the U.N. Office of the High Commission of Human Rights (OHCHR) expired without renewal for the first time since it began operations in Nepal in 2005, raising concerns about the government's commitment to human rights. A widespread culture of impunity has been linked to increasing violence across the country, as manifested by the assassination of Muslim leader Faizal Ahmad Ansari in broad daylight in Kathmandu in September by still unknown assailants. A wider climate of non-accountability exists, with periodic corruption scandals bedeviling both the commercial and political sectors.

\section{Economy, Infrastructure, and Disaster Preparedness}

Economic conditions remained grim in Nepal in 20II with a consumer inflation rate of approximately $9.5 \%$ and a rapidly growing fiscal deficit with

II. See Human Rights Watch, <http://www.hrw.org/news/20II/oI/I4/nepal-broaden-citizenshipprovisions $>$, accessed November I3, 20II. 
expenditures projected at $\mathrm{I} 4 \%$ above comparable figures for the previous year. ${ }^{12}$ Nepal's GDP for the fiscal year ending July I5, 20II, was US $\$ 18.3$ billion. Projected GDP growth for the coming fiscal year is 3.5\%, down over I\% from $4.6 \%$ in 2010 . Nepal has the tenth worst unemployment rate in the world, at around $46 \%$ of its population, ${ }^{13}$ with youth unemployment rates increasing especially rapidly. ${ }^{14}$ Many Nepalis continue to migrate overseas. As a result, a continued rise in remittance income remains one of the only positive economic indicators. According to one source, remittances account for $22 \%$ of Nepal's GDP. ${ }^{15}$ The real figure may be much higher due to inflow from India and informal channels. Tourism also provided some cause for optimism, with 2011 visitor arrivals by air up 21\% over 2010. ${ }^{16}$ In early December, the U.S. State Department lifted its Nepal travel alert for the first time since Nepal's conflict, raising hopes that tourism revenues would rise further in 20I2. Days later, this announcement was followed by the news that the U.S. Peace Corps would return to Nepal after suspending operations in 2004.

Nepal's decrepit infrastructure was thoroughly tested in 20Ir. Unable to meet rising demand, the country's energy sector increased scheduled power cuts to more than I2 hours per day, a process euphemistically referred to as "load shedding." Acknowledging Nepal's energy crisis, Finance Minister Bharat Mohan Adhikari launched a US\$275 million initiative in March to produce 2,500 megawatts of electricity within five years through the establishment of new hydro and solar stations, and tax breaks for investors. Electricity theft remains a problem, resulting in reduced domestic revenues through extensive "leakage."

Nepal's accident-prone aviation industry suffered two fatal setbacks in 20II, raising further questions about flight safety. One commercial and one

I2. Economist Intelligence Unit, Country Report: Nepal, August 20II, pp. IO-II. This formal publication is accessible only to subscribers to The Economist (ISSN I473-896I).

13. CIA World Factbook: Nepal, <https://www.cia.gov/library/publications/the-world-factbook/ geos/np.html>, accessed January 2, 2012.

I4. Mukesh Khanal, "Tackling Nepal's Unemployment Problem,” Republica, March 22, 20II, <http://archives.myrepublica.com/portal/index.php?action=news_details\&news_id=29445>, accessed January 2, 2012.

I5. World Bank, Poverty Reduction and Economic Management Sector Unit, South Asia Region, "Large-Scale Migration and Remittance in Nepal: Issues, Challenges, and Opportunities," June 23, 201 .

I6. "Visitor Arrivals Via Air up 2I PC in 20II," Nepalnews.com, January 2, 20I2, <http://www. nepalnews.com/home/index.php/news/I9/15695-visitor-arrivals-via-air-up-by-2I-pc-in-20Ir.html>, accessed January 2, 2012. 
army crash killed a total of 25 people, including several tourists. Travel by road in Nepal remains treacherous. For example, a bus accident in eastern Nepal on October 13 resulted in 43 fatalities. A major earthquake rocked the region on September I8. India's state of Sikkim, the epicenter of the quake, confirmed over 60 deaths. In contrast, Nepal reported only six fatalities, despite widespread structural damage. Concerns remain about Nepal's disaster management plan and general state of preparedness for natural calamities. Seismologists believe that a major earthquake in Kathmandu is simply a matter of time, an eventuality that, considering Nepal's existing political and economic challenges, would be devastating.

\section{BHUTAN}

Through a year of staggered elections and rebuilding after the September earthquake, Bhutan continued its transition from an absolute monarchy to a new, if constrained, parliamentary democracy. After mayoral elections on January 2I, the Election Commission of Bhutan organized the first nationwide poll to elect local government officials in 205 gewogs (counties) on June 27. Of Bhutan's 347,938 registered voters, $56 \%$ turned out to cast their ballots for the 2,I85 candidates. Costing close to US\$5 million, the election saw the deployment of 4,I25 electronic voting machines, more than twice the number used during the March 2008 general election. Some candidates formally resigned their party memberships to contest the election: Item 17 of Article 22 of Bhutan's 2008 Constitution states that "a candidate to or a member of the Local Governments shall not belong to any political party." Nevertheless, Bhutan's local electoral process was widely reported as being credible and transparent, even if some seats remain unfilled. On October 13, 20II, international guests gathered in the Punakha Dzong Palace alongside many of Bhutan's citizens to celebrate the marriage of 3I-year-old Western-educated King Jigme Singye Wangchuck to Jetsun Pema, a commoner Io years his junior.

Economic growth in Bhutan stabilized at $7 \%$ in 20II, underpinned by hydroelectric projects and continued electricity exports to India. While India remains Bhutan's single most important political and socioeconomic partner, accounting for $95 \%$ of Bhutan's exports and $74 \%$ of its imports, the significance of foreign remittances also continues to rise. In May, Bhutan and Nepal held talks to develop a preferential trade agreement between the two countries. In June, the Japanese government agreed to provide a loan 
of US\$27 million to electrify 3,549 Bhutanese households under the second phase of a rural electrification project.

The nation's "low impact, high yield" tourism strategy recovered in $201 \mathrm{I}$ after dips in previous years, drawing global attention to Bhutan's home-grown policy of "Gross National Happiness" (in lieu of gross domestic product [GDP]). ${ }^{17}$ Thanks to an agreement brokered by the U.N. High Commissioner for Refugees (UNHCR) formalizing third-country resettlement, gross national happiness continued to improve among Bhutanese refugees of Nepali origin. The I07,000 Nepali-speaking refugees, known as Lhotsampa, claim Bhutanese citizenship based on historical residence patterns. They have languished in refugee camps in Nepal's Tarai districts since the early I990s because of Nepal's, India's, and Bhutan's inability or unwillingness to resolve their citizenship status. ${ }^{18}$ The refugees are now accepting resettlement in eight Western countries: 40,000 of the 60,000 refugees offered settlement in the U.S. have already arrived, some noticeably malnourished and suffering from a vitamin BI2 deficiency. The many challenges aside, Bhutan in $201 \mathrm{I}$ continued on a path toward its own form of democracy.

I7. The term "gross national happiness" was coined in 1972 by Bhutan's then King Jigme Singye Wangchuck, in an attempt to define an indicator that measures quality of life or social progress in more holistic and psychological terms than the purely economic indicator of GDP.

I8. For further details, see Michael Hutt, Unbecoming Citizens: Culture, Nationhood, and the Flight of Refugees from Bhutan (New York: Oxford University Press, 2003). 